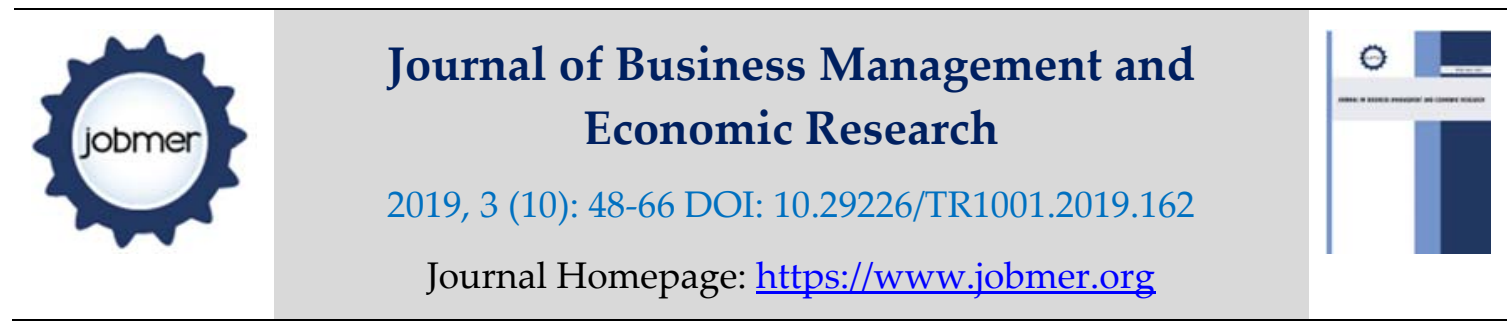

\title{
THE ROLE OF WORK MOTIVATION TO MEDIATE ASTA BRATA LEADERSHIP ON EMPLOYEE PERFORMANCE (STUDY ON LPD EMPLOYEES IN BADUNG REGENCY)
}

\author{
I Gusti Ayu Dewi Adnyani \\ Management Study Program of the Faculty of Economics and Business \\ Udayana University \\ igadewi@yahoo.com
}

I Gusti Agung Ngurah Jaya Widagda

Ni Nyoman Kerti Yasa

Putu Laksmita Dewi Rahmayanti

\begin{abstract}
This research was conducted with the background of the demand to excel in the business world, including Village Credit Institutions (LPD). The performance of LPDs in Badung Regency which tends to decline is an interesting phenomenon to be studied further. Declining employee performance can be influenced by employee motivation that has not been maximized and the leadership style applied by the manager. Leadership styles can encourage and motivate LPD employees to improve LPD performance. Therefore LPD in Badung Regency strives to improve the performance of its employees by providing maximum work motivation and developing leadership of Asta Brata so that the aim of the study is to examine the role of work motivation in mediating Asta Brata Leadership with the performance of LPD employees. This research was conducted in Badung Regency by taking a sample of 110 LPD employees. The analytical method used is SEM analysis. The results showed that Asta Brata Leadership had a positive and significant effect on LPD Employee Performance in Badung Regency. Asta Brata leadership has a positive and significant effect on the motivation of LPD employees in Badung Regency. Motivation has a positive and significant effect on LPD Employee Performance in Badung Regency. Motivation is able to mediate significantly in Asta Brata Leadership on employee performance. That is, by increasing motivation, the influence of Asta Brata Leadership on the performance of LPD employees in Badung Regency is increasing.
\end{abstract}

Keywords: Work motivation, Asta Brata leadership, employee performance, and LPD. 
Journal of Business Management and Economic Research (JOBMER), vol.3, issue.10, pp.48-66

\section{Introduction}

Increasingly tight competition today, is in desperate need of quality human resources to be able to face competition and change. If the performance achieved by the employee gets less attention, it can result in things that are not desirable, such as work that is not optimal. Therefore performance is very important to get attention and be known, both by the workers concerned and by their leaders. In connection with this, the leadership needs to be done so that motivation is maintained is to provide the right motivation to employees. By giving the right motivation, it is expected that each employee will be motivated to work better, so that employees arise in the belief that by working better according to the demands and desires of the organization, the goals of the organization will be more easily achieved and personal goals are fulfilled (Sriathi, 2003).

The current environmental changes are without exception also felt by microfinance institutions, including the Village Credit Institution (LPD). The development of the last LPD shows a somewhat declining performance due to the increasingly fierce competition faced by Rural Banks (BPR), Savings and Loans Cooperatives, and loan sharks. Quality human resources are needed in businesses that require a high level of work ethic such as the business of microfinance institutions, because the business of financial institutions is a business that relies heavily on trust. The community will entrust their financial affairs, both borrowing and saving money, to financial institutions that have good reputation, including the reputation of the managers. This good reputation certainly concerns the performance produced by a financial institution as an organization or company.

From the results of evaluations carried out on LPD employees in Badung Regency it is known that the majority of employees are not able to meet the targets set by the LPD, so this shows that the quality of employee work is low. In connection with not achieving the targets set by the LPD, so far employees have not been motivated to show maximum performance. One factor that influences performance is motivation. Motivation is a very important thing that every employee must have in order to be able to achieve the expected performance. Employee motivation can be seen from the attitude of his behavior that is full of enthusiasm in work and always strives to do the best job possible. Employees who have high motivation in an organization appear to be tireless in their work and always try to do their work as well as possible. 
Journal of Business Management and Economic Research (JOBMER), vol.3, issue.10, pp.48-66

LPDs in Badung Regency must pay attention to factors that can increase employee motivation in order to overcome company problems and improve their performance. Good performance is optimal performance, namely performance that meets standards and supports the achievement of organizational goals. Various methods are taken to improve employee performance through education and training, compensation and motivation. Employee performance issues can be implemented and can be solved if several variables that affect employee performance can be managed properly in the operational implementation.

The low performance of employees can be influenced by other factors, one of which is the leadership style applied by his supervisor. Leadership is one of the important factors that can give good influence to employees to maximize their work so that they are motivated to achieve company goals. A leader is a factor that closely determines the smoothness or drag of an organization or the success or failure of an organization. The quality of a successful leader is able to manage, anticipate sudden changes, correct weaknesses or by taking very wise steps. Asta Brata's leadership style plays a very important role for an organization to be able to achieve the organization's targets.

\section{Theoretical Review and Research Hypothesis}

\subsection{Work motivation}

Simamora (2009: 456) states that motivation is a psychological drive that directs a person toward a goal. Uzonna (2013) states motivation is a combination of needs, drivers and incentives. Motivation is defined as a process that begins with a physiological or psychological definition or need that activates behaviors intended for purpose or incentives. Muogbo (2013) states motivation comes from the word "motivate", meaning steps, encouragement or influence to continue something in order to fulfill the desire. Usman (2013: 275) states that motivation is a tool used so that subordinates want to work hard and work smart as expected.

Encouragement or motivation to work is very important for company productivity. Without the motivation of employees or workers to work together for the interests of the company, the stated goals will not be achieved. As said by Gayle \& Searle, 2000 (Marhaeni, 2011), understanding the 
Journal of Business Management and Economic Research (JOBMER), vol.3, issue.10, pp.48-66

factors that can motivate a person will be very helpful in fostering successful relationship management and employees.

\subsection{Asta Brata's Leadership}

Leadership is the process of leading, managing, moving and running an organization, institution, bureaucracy, and so on. Leadership also means values or values that are difficult to measure because they relate to mental processes, this is related to leadership as authority. In leadership there is always an unequal division of power between leaders and those who are led. Therefore the leader must have something more than the leader, the leader is an example, a role model, which is worthy of his members.

Asta brata as the eight noble qualities of the gods in Hindu view is considered as an adequate component to provide service to the community. The eight components of leadership according to Asta brata as explained in the Kakawin Ramayana and the books of Manaiua Dharnia sastra are as follows: Indra Brata, Yama Brata, Surya Brata, Chandra Brata, BayuBrata, KuweraBrata (Dana Brata), Barurna (WarunaBrata) and Agni Brata

\subsection{Employee Performance}

Employee performance in this study is the achievement of employees' work on the duties and authorities that have been given by the company in accordance with the capabilities and competencies of the employees both in terms of quantity and quality to achieve the goals, vision and mission of the company and the quality of an employee to achieve organizational goals.

\section{Research Concept Framework}

The conceptual framework in research refers to several previous studies (journals) relating to employee performance. Previous research related to research variables, among others, by Setiawan (2013) found motivation has a positive influence on performance.

Leadership performance also proved to influence organizational performance improvement (Prabhu and Robson, 2000; Lee and Yu, 2004; Gunawan, 2009; Kamaliah, 2012; Hidayat, 2011; and Koesmono, 
2011). Pande Juliana (2012) said that the influence of the leadership of Asta Brata had a positive influence on performance.

Based on the conceptual framework that explains the interrelations of each variable, a conceptual framework is arranged as shown in Figure 1

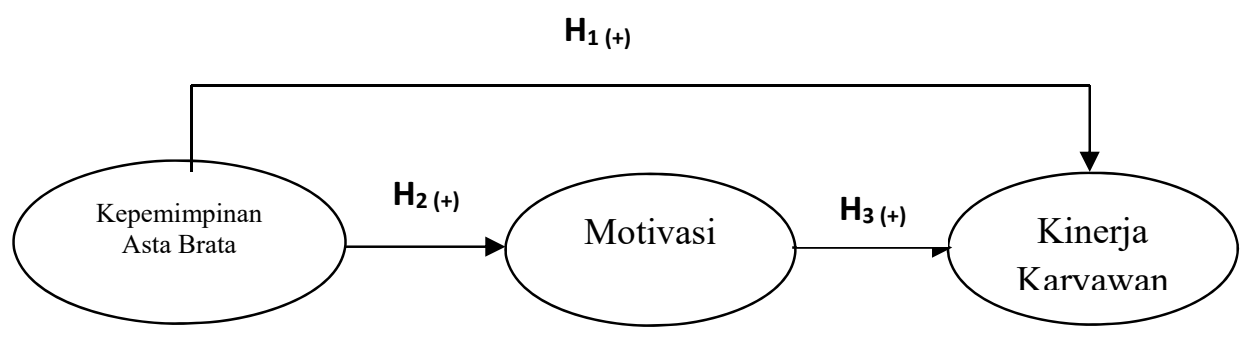

Figure 1. Conceptual Framework of the Research

3.1. Research Hypothesis: Based on the existing conceptual framework, the research hypothesis that can be prepared is as follows:

H1: The leadership of Asta Brata has a positive and significant effect on employee performance

$\mathrm{H}_{2}$ : The leadership of Asta Brata has a positive and significant effect on motivation

$\mathrm{H}_{3}$ : Motivation has a positive and significant effect on employee performance.

$\mathrm{H}_{4}$ : Motivation is able to mediate the leadership of Asta Brata on employee performance.

\subsection{Research Method}

This research is a type of causality research, which aims to examine the causality relationship between Asta Brata leadership variables and work motivation, as well as employee performance. This research will be conducted at LPD in Badung Regency. This study took the subject of LPD in Badung Regency with the object of research about the leadership of Asta Brata, work motivation and employee performance. Based on the problem formulas and hypotheses developed, the variables in this study can be identified as follows: 
Journal of Business Management and Economic Research (JOBMER), vol.3, issue.10, pp.48-66

1) Endogenous variables, namely latent variables whose values are determined by other variables in the model / subject to arrows or archery (Solihin and Ratmono, 2013). The endogenous variable in this study is employee performance (Y1).

2) Intervening variable, which is a variable that influences the relationship between dependent variables to an indirect relationship and lies between the dependent variable and the independent variable, so that the independent variables indirectly affect the dependent variable (Indriantoro and Supomo, 2012: 66). The mediation variable in this study is work motivation (Y2).

3) Exogenous variables, namely latent variables whose values are determined by other variables outside the model / model that are not subject to arrows (Solihin and Ratmono, 2013). The exogenous variable in this study is the Leadership of Asta Brata $(X)$.

To define variables related to the object of research, several definitions of operational variables are explained as follows:

\section{Employee Performance (Y2)}

Employee performance in this study is the achievement of employee's work on the duties and authorities that have been given by the company in accordance with the capabilities and competencies of the employee both in terms of quantity and quality to achieve the goals, vision and mission of the company.

The indicator used to measure employee performance in this study uses the indicators used by Mathis and Jackson (2009) as follows:

1) Quantity of work (Y2.1)

Describe the fulfillment of the targets that have been set so that it shows the ability of the organization in managing the resources owned to achieve its goals. This indicator is measured from the perceptions of respondents that employees are able to do the work in accordance with the specified quantity, number / volume of work in accordance with organizational expectations.

2) Quality of work (Y2.2) 
Journal of Business Management and Economic Research (JOBMER), vol.3, issue.10, pp.48-66

Describe the completion of the work in accordance with the demands of the organization. This indicator is measured by the perception of respondents that employees are able to do the work in accordance with the quality set by the organization.

3) Working time (Y2.3)

Describe the working time that is considered the most efficient and effective at all levels of management. Work time is the basis for employees to complete work that is their responsibility. This indicator is measured by the respondent's perception of being able to complete the work on time, able to use time effectively and efficiently.

4) Cooperation with co-workers (Y2.4)

It is a guide for the success of an organization in achieving its stated goals. Good cooperation will give confidence to various stakeholders, both directly and indirectly with the company. This indicator is measured by respondents' perceptions of being able to work with colleagues, always being positive in each group's work.

5) According to SOP (Y2.5)

Describe the completion of the work in accordance with the SOP that has been set by the organization. This indicator is measured by the perception of respondents that employees are able to do work according to SOPs that already exist in the LPD.

\section{Work Motivation (Y1)}

Motivation $\left(\mathrm{Y}_{1}\right)$ in this study is a process that evokes an inner motivation of employees towards achieving the goals set by the company (Robbins and Judge, 2012: 217). Motivational variables can be measured by the dimensions and indicators as follows:

(1). Need for achievement

Need for achievement (nAch) or achievement motivation is the need and effort of employees in developing creativity and directing all the capabilities and energy they have to achieve maximum work performance. The indicators of Need for achievement (nAch) are: 
Journal of Business Management and Economic Research (JOBMER), vol.3, issue.10, pp.48-66

a) Job challenges: Job challenges are the level of difficulty for employees who will be faced at the beginning in carrying out their work. Job challenges according to the perspective of respondents are able to complete difficult work.

b) Responsibility: Responsibility is the demands and obligations given by the company to its employees in carrying out the type and work load that has been set. Responsibility according to the respondent's perspective is able to contribute all abilities in completing work.

c) Need for awards: The need for rewards is a very basic need for an employee, owned by employees on an ongoing basis such as salary, wages, incentives, and other benefits. The need for awards according to the respondent's perspective is satisfied with the award given by the company.

d) Need for achievement: The need for achievement is an encouragement for employees to be the best in the company. The need for achievement according to the respondent's perspective consists of showing work performance in completing each job.

(2). Need for Power

Need for Power (nPO) or motivation for power and strength is the need to have strength and as a benchmark to achieve a leadership position in the company. The indicators of Need for Power (nPO) are

a) The role of leadership: The role of leadership is the role that superiors and employees have in influencing their subordinates and colleagues in supporting company performance. The role of leadership according to the perspective of the respondent is able to become a role model for colleagues in the company.

b) Orientation on increasing position status: Orientation on increasing the status of the position is a motivation for employees to improve their status and prestige in the company to get a higher position than other employees. Orientation to increase position status according to respondent's perspective has good potential to develop a career in work.

\section{(3). Need for Affiliation}

Need for Affiliation or the need to be affiliated or related is an urge to interact with the work environment in this case, namely superiors and co-workers. The need to expand this association has the motivation to cooperate 
Journal of Business Management and Economic Research (JOBMER), vol.3, issue.10, pp.48-66

\section{Asta Brata Leadership (X)}

Asta Brata is an ethical and moral teaching that contains various aspects of life, especially regarding the leadership principles that must be possessed by a leader. Asta Brata consists of the word "Asta" which means eight and "Brata" which means grip or guidelines. So Asta Brata is eight guidelines or guidelines that must be owned by a leader. The teachings of Asta Brata mention the nature of God which makes strength for his people and describes the abilities that must be possessed by a leader, as follows:

(1) Indra Brata (X1)

A leader must be able to provide pleasure, protect, and provide welfare to subordinates or people who are led. This indicator is measured by the perception of respondents that the leader must be able to protect subordinates

(2) Yama Brata (X2)

A leader must be able to act fairly and decisively, punish or impose sanctions on the wrong and reward those who excel. This indicator is measured by the perception of respondents that the leader must be able to act fairly

(3) Surya Brata (X3)

A leader must be able to provide lighting and strength to those who are led. This indicator is measured by the perception of respondents that the leader must be able to provide information to subordinates

(4) Chandra Brata (X4)

A leader must be able to provide coolness and comfort to his subordinates. This indicator is measured by the perception of respondents that the leader is able to provide coolness (5) Bayu Brata (X5)

A leader must understand the ikhwyal of people who are led. This indicator is measured by the perception of respondents that the leader must be able to understand the matters of the people he leads

(6) Kuwera Brata (X6) 
A leader must look sympathetic and neat, both in appearance and in words. This indicator is measured by the perception of respondents that the leader is able to look sympathetic

(7) Baruna Brata (X7): leaders must have broad knowledge or insight so they are able to control "their subordinates with wisdom and wisdom. This indicator is measured by the perception of respondents that the leader has broad insight.

(8) Agni Brata (X8)

A leader should be able to motivate and inspire subordinates. This indicator is measured by the perception of respondents that the leader is able to arouse subordinate enthusiasm

\section{Results and Discussions}

\subsection{The Effect of Motivation to Mediate Leadership of Asta Brata}

Examination of equation 1 is done by looking at the influence of motivating to supervise the leadership of Asta Brata which is done using the SPSS program. Based on the data processing, the regression test results can be presented in Table 1.

Table 1. Asta Brata Leadership Regression Test Results Against Motivation

\begin{tabular}{|c|c|c|c|c|c|}
\hline \multirow{2}{*}{ Model } & \multicolumn{2}{|c|}{$\begin{array}{l}\text { Unstandardized } \\
\text { Coefficients }\end{array}$} & \multirow{2}{*}{$\begin{array}{l}\text { Standardized } \\
\frac{\text { Coefficients }}{\text { Beta }}\end{array}$} & \multirow{2}{*}{$t$} & \multirow{2}{*}{ Sig. } \\
\hline & B & $\frac{\text { Std. }}{\text { Error }}$ & & & \\
\hline (Constant) & $0,102 \quad 0$ & & & & \\
\hline $\begin{array}{l}1 \\
\text { AstaBrata } \\
\text { Leadership }\end{array}$ & 0,985 & 0,054 & 0,872 & 18,093 & 0,000 \\
\hline$R_{1} 2$ & & & & & 0,288 \\
\hline F Statistic & & & & & 39,553 \\
\hline Sig F & & & & & 0,000 \\
\hline
\end{tabular}

Source: Primary data, processed (2018) 
Table 1 shows the results of the regression test the effect of value perception mediating the use of social media with the value of Sig. 0,000<0,05 indicates that the leadership of Asta Brata has a positive and significant effect on motivation.

4.2. The Effect of Asta Brata's Motivation and Leadership on Performance

Table 2. Leadership and Motivation Regression Test Results Against Performance

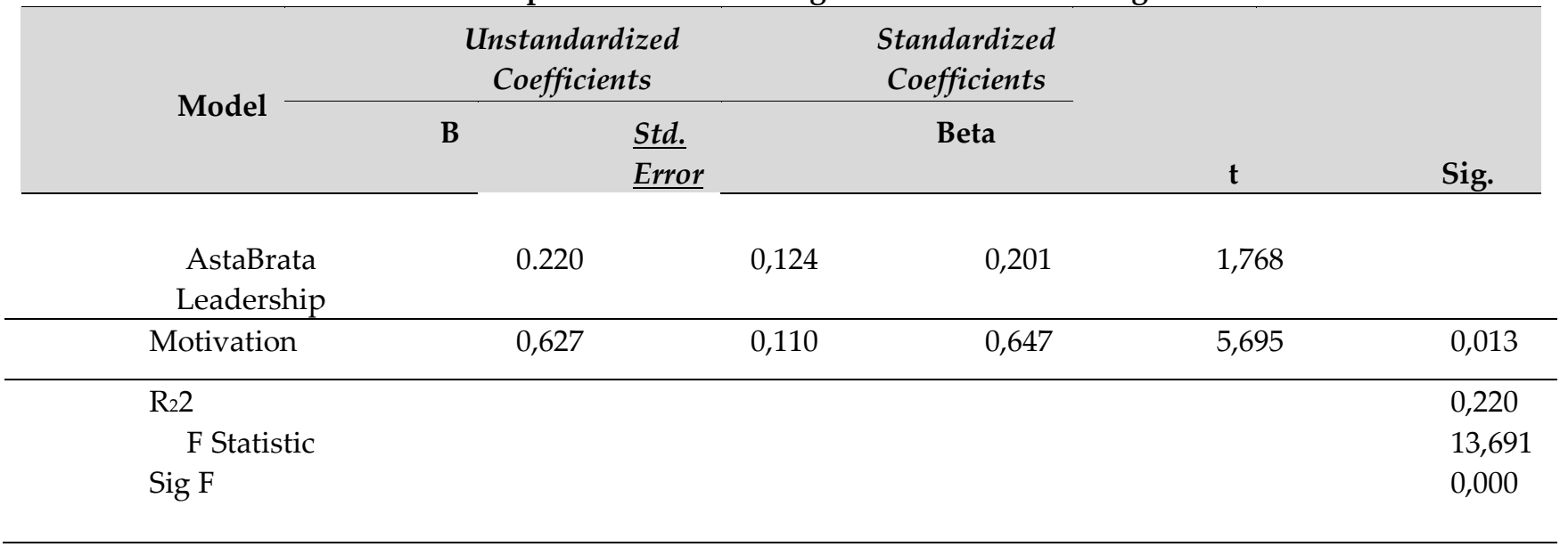

Source: Primary data, processed (2018)

Table 2 shows the results of the regression test of the influence of motivation and leadership of Asta Brata on performance. Asta Brata leadership with Sig. $0.014<0.05$ indicates that the leadership of Asta Brata has a positive and significant effect on performance. Motivation with Sig. $0.013<0.05$ indicates that motivation has a positive and significant effect on performance.

\subsection{Path Analysis Test Results}

Based on the results of data processing, it can be made the relationships between research variables which are the path coefficients in this study. Path coefficients can be made in the form of path diagrams. The model can also be expressed in structural equations, namely. 
1) Structural equation 1

$\mathrm{Y} 1=0,872 \mathrm{~B} 1 \mathrm{X}$

2) Structural equation 22

$\mathrm{Y} 2=0,201 \mathrm{~B}_{2} \mathrm{Y} 1+0,647 \mathrm{~B}_{3} \mathrm{X}$

\subsection{Evaluation of Model Validity}

Based on the results of the data shown in the summary of the path coefficients shown in Table 3 which explains that the Asta Brata Leadership variable (X) has a significant effect on Motivation (Y1), Motivation Variable (Y1) has a significant effect on Performance (Y2), and the Asta Brata Leadership Variable $(\mathrm{X})$ has a significant effect on Performance (Y2).

Table 3. Summary of Path Coefficients

\begin{tabular}{|c|c|c|c|c|c|}
\hline Regression & & $\begin{array}{l}\text { Koef. } \\
\quad \text { Regr } \\
\text { ession } \\
\text { Estandar }\end{array}$ & $\begin{array}{l}\text { Standard } \\
\text { Error }\end{array}$ & $\begin{array}{l}\text { t } \\
\text { test }\end{array}$ & $\begin{array}{l}p \\
\text { value }\end{array}$ \\
\hline $\mathrm{X} \rightarrow \mathrm{Y}_{1}$ & 0,872 & 0,054 & 0,872 & 0,000 & signifikan \\
\hline $\mathrm{X} \rightarrow \mathrm{Y}_{2}$ & 0,201 & 0,110 & 0,647 & 0,014 & signifikan \\
\hline $\mathrm{Y}_{1} \rightarrow \mathrm{Y}_{2}$ & 0,647 & 0,214 & 0,201 & 0,013 & signifikan \\
\hline
\end{tabular}

Noted :

$X=$ Asta Brata Leadership

$\mathrm{Y} 1=$ Motivation

Y2 = Performance

ed on data processing the summary of path cooeficient can be illustrated in Figure 2 


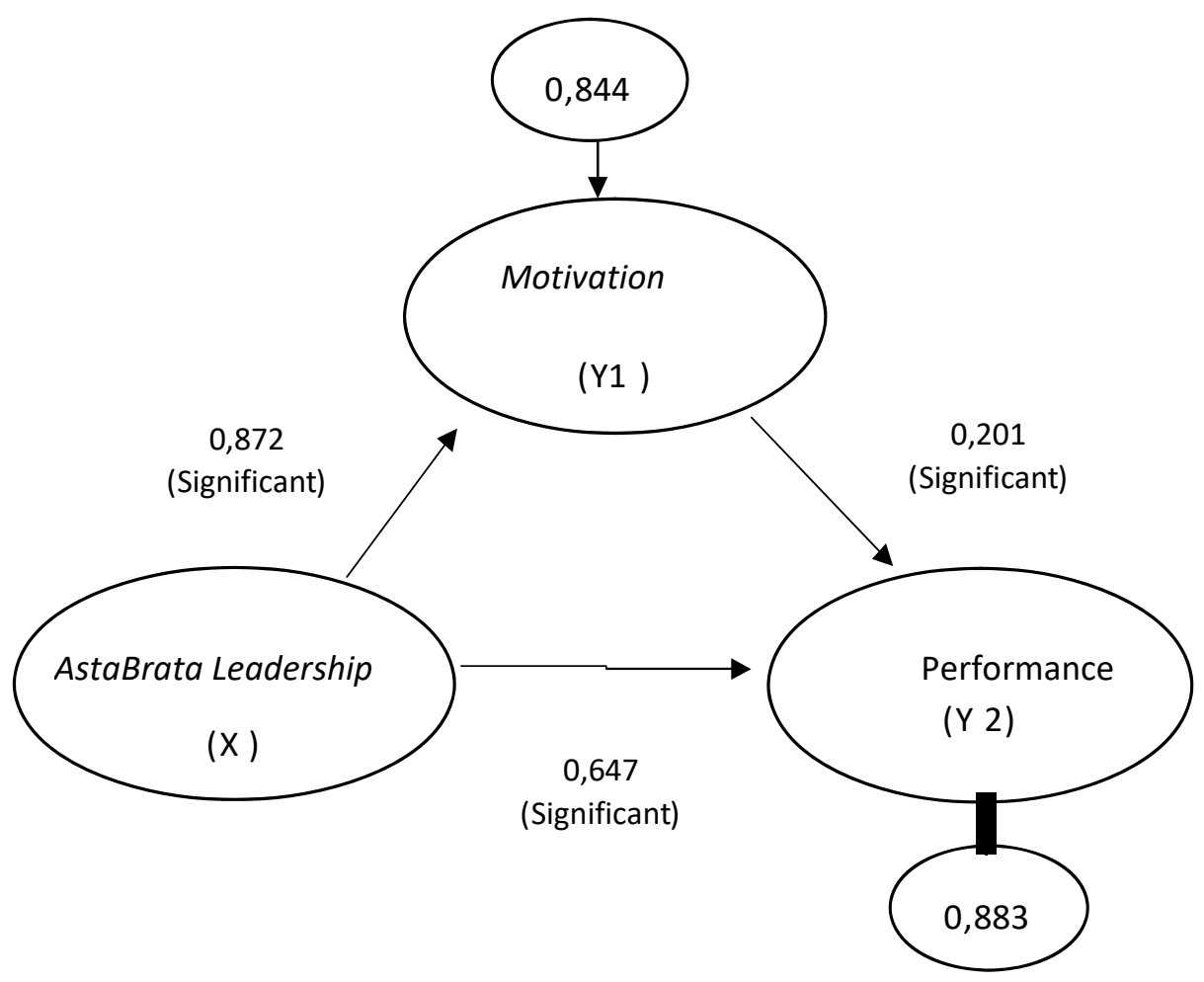

Figure 2

Based on figure 2, direct effect, indirect effect and effect among variables can be calculated in Table 7

Table 4. Summary of Direct Effect, Indirect Effect and Total Effect Among Research Variables

\begin{tabular}{llll}
\hline $\begin{array}{l}\text { Variable } \\
\mathbf{X}\end{array}$ & PL & PTL & \\
& T1 & 0,872 & \\
\hline Y2 & 0,647 & 0,144 & 0,536 \\
\hline
\end{tabular}

Noted:

PL $\quad=$ Direct Effect $/$ PengaruhLangsung

PTL $\quad=$ Indirect Effect

/PengaruhTidakLangsung

$\mathrm{TP} \quad=$ Total Effect

$\mathrm{X}=$ Asta Brata Leadership

$\mathrm{Y} 1 \quad=$ Motivation 
Journal of Business Management and Economic Research (JOBMER), vol.3, issue.10, pp.48-66

$\mathrm{Y} 2$

$=$ Performance

In Table 4 the direct effect of $\mathrm{X}$ on $\mathrm{Y} 1$ is 0.872 ; there is no indirect effect so the total effect is 0.872 . The direct effect of $\mathrm{X}$ on $\mathrm{Y} 2$ is 0.647 . The indirect effect of $\mathrm{X}$ on $\mathrm{Y} 2$ through $\mathrm{Y} 1$ is obtained from $0.872 \mathrm{x}$ $0.647=0.144$. Therefore, the total effect of $\mathrm{X}$ on $\mathrm{Y} 2$ through $\mathrm{Y} 1$ is $0.647+0.144=0.411$. This means that there is an indirect influence of the AstaBrata Leadership variable on performance through motivation

Based on the calculation of the total determination coefficient, it is obtained that the diversity of data that can be explained by the model is $44.5 \%$ or in other words the information contained in the data of $44.5 \%$ can be explained by the model while the remaining $55.5 \%$ is explained by variables others that are not in the model

Direct Influence Discussion

1) The direct influence of Asta Brata's leadership on motivation

i) Hypothesis Formulation

H0: The leadership of Asta Brata has no positive and significant effect on motivation.

H1: The leadership of Asta Brata has a positive and significant effect on motivation

ii) Significant level of 5\% 95\% confidence level $(\alpha=0.05)$

iii) Testing Criteria

If the probability value is greater than the value $\alpha=0.05(\mathrm{p}>0.05)$

then $\mathrm{Ho}$ is accepted and $\mathrm{H} 1$ is rejected. If the probability value is smaller or equal to the value of $\alpha=$ $0.05(\mathrm{p}<0.05)$, then $\mathrm{H} 0$ is rejected

and $\mathrm{H} 1$ is accepted.

iv) Calculation Based on calculations using the SPSS program, the standardized coefficient beta value is 0.536 and the probability value is 0.000 .

v) Conclusions

The probability value is $0,000<0,05$. This means that $\mathrm{H} 0$ is processed and $\mathrm{H} 1$ is accepted. Thus the leadership of Asta Brata has a positive and significant influence on motivation. 
Journal of Business Management and Economic Research (JOBMER), vol.3, issue.10, pp.48-66

A positive and significant relationship between the Asta Brata Leadership variables on Motivation variables, thus the leadership of Asta Brata has a positive and significant effect on motivation. This is because if the leadership of Asta Brata is always carried out by the LPD leadership, the work motivation of the LPD employees over time will always increase. This is consistent with the results of a study by Stockdale et al. (2012); and McCann and Barlow (2015).

2) The direct influence of Asta Brata's leadership on performance

i) Hypothesis Formulation

H0: The leadership of Asta Brata does not have a positive and significant effect on performance

H1: The leadership of Asta Brata has a positive and significant influence on

Performance

ii) Significant level of 5\% 95\% confidence level $(\alpha=0.05)$

iii) Testing Criteria

If the probability value is greater than the value of $\alpha=0.05(\mathrm{p}>0.05)$ then $\mathrm{H} 0$ is accepted and $\mathrm{H} 1$ is rejected. If the probability value is smaller or equal to the value of $\alpha=0.05(\mathrm{p}<0.05)$, then $\mathrm{H} 0$ is rejected and $\mathrm{H} 1$ is accepted.

iv) Calculation

Based on calculations using the SPSS program, the standardized coefficient beta value is 0.267 and the probability value is 0.014 .

v) Conclusions

The probability value is $0.014<0.05$. This means that $\mathrm{H} 0$ is rejected and $\mathrm{H} 1$ is accepted. Thus the leadership of Asta Brata has a positive and significant effect on performance.

A positive and significant relationship between the Asta Brata leadership variables and the performance variables states that the more LPDs implement leadership, the LPD performance will increase over time. The results of this study also strengthen the results of previous studies conducted by Fiscer and Reuber (2011); Montalvo (2011); and Divol et al. (2012).

3) Effect of Motivation on Performance 
Journal of Business Management and Economic Research (JOBMER), vol.3, issue.10, pp.48-66

i) Hypothesis Formulation

H0: Motivation does not have a positive and significant effect on performance

H1: Motivation has a positive and significant effect on performance.

ii) Significant level of 5\% 95\% confidence level $(\alpha=0.05)$ iii) Testing Criteria

If the probability value is greater than the value of $\alpha=0.05(p>0.05)$ then $\mathrm{H} 0$ is accepted and $\mathrm{H} 1$ is rejected. If the probability value is smaller or equal to the value of $\alpha=0.05(\mathrm{p}<0.05)$, then $\mathrm{H} 0$ is rejected and $\mathrm{H} 1$ is accepted.

iv) Calculation

Based on calculations using the SPSS program, the standardized coefficient beta value is 0.269 and the probability value is 0.013

v) Conclusions

The probability value is $0.013<0.05$. This means that $\mathrm{H} 0$ is rejected and $\mathrm{H} 1$ is accepted. Thus

Motivation has a positive and significant effect on performance.

Positive and significant relationship between motivation variables on performance, this means that motivation can contribute to shaping the dominant performance. The higher the employee's work motivation, the contribution in improving performance will be easily achieved. It can be concluded that, motivation has a positive and significant influence on performance, this means, with the higher work motivation felt by LPD employees, it will further improve performance achievement.

Discussion of Indirect Influences

Mediation test of motivation variable (Y1) on the relationship of leadership of Asta Brata (X) to Performance (Y2)

i) Hypothesis Formulation

H0: Motivation is not a mediating variable of Asta Brata's leadership relationship to performance.

H1: Motivation as a mediating variable of Asta Brata's leadership relationship to business performance

ii) Testing Criteria 
a) If $Z$ counts 961.96 then $\mathrm{H} 0$ is accepted, meaning motivation is not is a mediating variable.

b) If $\mathrm{Z}$ counts $>1.96$ then $\mathrm{H} 0$ is rejected, meaning motivation is a mediating variable.

iii) Calculation

To test the mediator variable mediating the relationship between the dependent variable and the independent variable can be done as follows:

Conclusion

Therefore $\mathrm{Z}$ count is $2.96>1.96$ This means that motivation ( $\mathrm{Y} 1)$ as a mediating variable indirect effect of Asta Brata (X) Leadership on Performance (Y2)

Motivational variables as mediating variables have a significant indirect effect on performance through the leadership variable Asta Brata. Therefore, with the perceived work motivation, the leadership of Asta Brata has a stronger influence on performance achievement.

\section{Practical Implications}

This research can contribute ideas for LPD managers and management. The intended contribution of thought is that the LPD always develops the leadership of Asta Brata in order to provide benefits or value to the business so as to improve the performance of the LPD.

\section{Research Limitations}

Various limitations are also found in this study mainly due to the following.

1. This study only uses respondents in the credit section of the LPD so that the results of the study cannot be fully generalized. 
2. The mediating variable studied is the value motivation variable which turns out that in this study significant influence on performance, so in the future it needs to be considered to choose other mediating variables.

\section{Conclusion}

Based on the discussion it can be concluded that 1) Asta Brata's leadership has a positive and significant effect on LPD Employee Performance in Badung Regency, 2) Asta Brata's leadership has a positive and significant effect on the motivation of LPD employees in Badung Regency, 3) Employee motivation has a positive and significant effect on performance LPD employees in Badung Regency and 4) Motivation is able to significantly mediate the leadership of Asta Brata on employee performance.

\section{Bibliography}

Alhamda, S. danSanusi, R. 2006. Persepsi Perilaku Kepemimpinan, Perilaku Sebagai Warga Organisasi Dan Kinerja Dosen Politeknik Kesehatan Padang Sumetara Barat. Working Paper Series, No.8 April 2006. Program Magister Kebijakan Dan Manajemen Pelayanan Kesehatan. Universitas Gadjah Mada. Yogyakarta.

Bachrach, G.D., Powell, C., Benjamin, Bendoly, E., and Richey, G.R. 2006. Organizational Citizenship Behavior And Performance Evaluations: Exploring The Impact Of Task Interdependence. Journal Of AppliedPsychology. Vol. 91, No. 1, pp. 193-201.

Denison. 1990. Cooporate Culture And Organizational Effectiveness, Willey.

Newyork.

Hameed Abdul, WaheedAamer., 2011. Employee Development and Its Affect on Employee Performance Framework, International Journal of Businessand Social Science, Vol. 2 No. 13, pp.224-229.

Indriani,E. danWaluyo, H. 2012. Pengaruh Kepemimpinan Dan Budaya Organisasi Terhadap Kinerja Pegawai Negeri Sipil Di Sekretariat Daerah Kabupaten Karanganyar Dengan Komitmen Organisasi Sebagai Variabel Intervening. Jurnal Edisi.

Koesmono,T.H. 2011. Pengaruh Budaya Organisasi Dan Kepemimpinan Terhadap Kinerja Melalui Variabel Mediasi Komitmen Organisasional Karyawan Perusahaan Swasta Di Surabaya Timur. Jurnal Mitra Ekonomi Dan Manajemen Bisnis. Vol. 2, No. 2, hal.155-171.

Lim, B. 1995. Examining The Organizational culture And Organizational Performance Link. Leadership \& Organization Development Journal. Vol. 16 No. 5, pp. 16-21. 
Journal of Business Management and Economic Research (JOBMER), vol.3, issue.10, pp.48-66

Ojo, O. 2009. Impact Assessment Of Corporate CultureOn Employee Job Performance. Business Intelligence Journal. Vol. 2 No. 2.

Pande Juliana.2012.wordpress.com/2012/05/24/asta-bratha-ajaran-kepemimpinan-menuruthindu-part-2

Podsakoff,P.M. Ahearne, M. and Mackenzie, S.B. 1997. Organizational Citizenship Behavior And The Quantity And Quality Of Work Group Performance. Journal Of Applied Psychology. Vol.82. pp.262-270.

Porter, M.M. 1979. How Competitive Forces Shape Strategy. Harvard Business Review.

Sekaran, U. 2003. Research Methods for Business. A Skill Building Approach.

John Wiley \& Sons, Inc.

Shahzadi, Irum., Ayesha Javed., Syed ShahzaibPirzada., ShaguftaNasreen., Farida Khanam.2014. Impact of Employee Motivation on Employee Performance. European Journal of Business and Management, Vol.6, No.23.

Sugiyono., 2014. Metode Penelitian Kuantitatif Kualitatifdan REB. Bandung:

Alfabeta.

SugiyantodanSutanto, H. 2010. Membangun Etos Kerja Yang Pro Aktif Guna Mengoptimalkan Kinerja Melalui Spiritual Centered Leadership, Employee Empowerment, Organizational Citizenship Behavior. Buletin Ekonomi. Vol. 8 No. 2, Hal.70-170.

Zameer, Hashim.,Shehzad, Ali., Waqar, Nizar and Muhammad, Amir. 2014. The Impact of the Motivation on the Employee Performance in Beverage Industry of Pakistan. International Journal of Academic Reseacrh inAccounting, Finance and Management Sciences.Vol. 4, No. 1, pp:293-298 